A. S. Mamatova, Z. B. Sakipova, R. B. Aiupova, G. S. Serikova

Kazakh National Medical University named after S. D. Asfendiyarov, Almaty

\title{
ANALYSIS OF KAZAKHSTAN PHARMACEUTICAL MARKET OF DRUGS USED IN PARADONTOPATHY
}

This article presents the results of a study of the pharmaceutical market of Kazakhstan, Russia, Ukraine, here is studied the range of drugs used in parodontopathy. Analyzed the structure of market, in accordance with the groups of drugs (ATC-classification), dosage form, composition of the active ingredients. Particular attention in this segment of drugs is given to Kazakhstan pharmaceutical market. Studied the structure of manufacturing countries (Kazakh manufacturers hold only 13\% of the market ), highlighted the possibilities and directions of development of the domestic pharmaceutical industry in this segment.

Key words: pharmaceutical market; dental drugs; paradontopathy; Republic of Kazakhstan; marketing analysis

\section{STATEMENT OF THE PROBLEM}

In recent years is rapidly growing market of dental services and great attention is paid to inflammatory diseases of the oral cavity and, in particular, the methods of treatment of periodontitis. This is due to the fact that these diseases can be the trigger for the emergence of a number of systemic diseases. Thus, close relationship between the set of oral diseases and diseases such as bacterial pneumonia, chronic obstructive pulmonary disease, bone disease, gastrointestinal disease, etc. [1, 3, 12, 13].

Inflammatory processes in the periodontium have a significant distribution and periodontal disease is a rare disease (2-3\% of all periodontal diseases). Recent studies prove conclusively that the inflammatory periodontal disease (IPD) is not only the most widespread among the population, but also have an expressed multicomponent effect on the body.

In the Republic of Kazakhstan are also prevalent oral diseases among adults and among children. They are characterized by varying severity, premature loss of teeth and the possible formation of foci of chronic infection, so the search for drugs for their prevention and treatment is topical $[4,5,7$, 9]. Particular importance is attached to treatment of the following periodontal diseases:

- inflammatory periodontal diseases - gingivitis, periodontitis;

- degenerative diseases - periodontitis.

(c) Mamatova A. S., Sakipova Z. B., Aiupova R. B., Serikova G. S., 2016
To the drugs used in the treatment of gingivitis and periodontitis, are given special requirements, namely multidirectional action - presence of an antimicrobial, immunomodulatory, dehydrating effects. Also, these drugs must provide stable drug concentration in the place of inflammation, not cause side effects, be stable during storage. The most efficient local dosage form, which allows to implement multifactorial, prolonged effect on periodontal tissue lesions is a gel form of the drug.

\section{ANALYSIS OF RECENT RESEARCH AND PUBLICATIONS}

Some theoretical and practical issues concerning the factors stimulating the development of these diseases, as well as the methods and principles of use and parapharmaceutical drugs in the form of gel in the treatment of periodontal disease are investigated worldwide. In particular, in Kazakhstan, principles and features of the treatment are covered in works of G. S. Stabaeva, V. P. Rusanov [5, 7], in Russia - O. A. Tsarahova [4, 10], in Ukraine N. I. Gumenyuk [3], S. A. Tereshchuk [9] and of many other scholars and practitioners $[6,12,13]$.

\section{IDENTIFICATION OF ASPECTS OF THE PROBLEM UNSOLVED PREVIOUSLY}

In dental practice, except for special dental materials, are used drugs of different pharmacological groups. Local anesthetic, analgesic, astringent, antiinflammatory, antihistamine, enzyme [9], by means of stimulating the regeneration of tissues [10], etc., and with microbial lesions of the oral cavity - an- 
tibiotics and other antimicrobials. Of great importance are also drug prevention and drug treatment of dental caries, periodontitis, parodontopathies and others. However, to date the marketing studies of the pharmaceutical market of Kazakhstan in relation to the drugs used in inflammatory diseases of the oral cavity are fragmented. All this determined the purpose and objectives of the study.

\section{OBJECTIVE STATEMENT OF THE ARTICLE}

Aim of the study was to analyze the range of pharmaceutical and medicinal drugs for the prevention and treatment of oral diseases, present in the pharmaceutical market of Kazakhstan.

\section{PRESENTATION OF THE MAIN MATERIAL OF THE RESEARCH}

Analysis was conducted using the National Registry of Kazakhstan [2], Russia directories of drugs [11], and Ukrainian ones [8], scientific literature and Internet sources.

To achieve the goal the following tasks were solved: to determine the presence and structure of the range of drugs used for the prevention and treatment of oral diseases presented at the market of Kazakhstan (local use).

Today at the Kazakhstan market is presented a wide range of drugs in various dosage forms used to treat inflammatory diseases of the oral cavity. Are used solutions, rinses, powders, pastes, ointments, emulsions, aerosols, etc. However, each form has certain disadvantages, such as: unevenness of contact of active components with the mucous membrane of the mouth, shortness of their interaction with tissues, rapid decrease in the concentration due to dilution of saliva and elution of drugs into the lower gastrointestinal tract. In this connection, in the dental practice for the treatment of this group rational is to use dental gels, as this dosage form provides a greater effectiveness of pharmacotherapy.

Gels have many advantages over other dosage forms: they retain their shape for a long time, easily applied to the surface of the mucous membranes, including oral mucosa, are able to be retained on it for a long period of time (so that a long time is provided in contact with mucosal tissue). Due to the high viscosity of the dispersion medium is possible adding into gels chemically incompatible components, as dispersion medium interferes with the interaction between them. Therefore, special attention was paid to the assortment and evaluation of dental gels.

During the analysis of the pharmaceutical market of Kazakhstan, Russia, Ukraine, was formed a list of trade names of drugs most commonly used for the treatment and prevention of periodontal disease (Table). Market of dental products for topical application is represented by 29 names, of which 22 drugs are registered in Kazakhstan, in Russia 16 drugs, and in Ukraine - 19 drugs.

Most of the drugs (90\%) are complex. The most popular compositions of the studied drugs include metronidazole and chlorhexidine digluconate, at least at part of the active substances is found lidocaine, and even less the drugs include herbal extracts.

Regarding the release forms the large part are gels $(n=14)$, then solutions $(n=5)$, sprays $(n=2)$, tablets $(n=2)$, pastilles $(n=2)$, paste $(n=1)$, ointment $(n=1)$. Only 3 of the drug are manufactured by Kazakh industry (Rotokan, Kamesan, Topolin), they all refer to the drugs made of herbal raw materials and are different in composition. Of the 14 drugs in the form of gels, only one drug - is manufactured in Kazakhstan, other drugs are presented by foreign manufacturers.

According to ATC classification list of products consists mainly of drugs group A01A "Dental drugs", which includes: subgroup A01AB "Anti-infectives and antiseptics for local treatment of oral diseases" (A01A B12, A01A B67, A01AB11, A01A B53, A01A B09, A01A B53), subgroup A01AD “Other drugs for the treatment of oral diseases” (A01AD11), as well as drugs of a group D01A "Antifungals for topical use" (D01A C01).

We studied drugs range depending on the form (solutions, ointments, gels, tablets, lozenges, pastes), as well as their specific gravity (Fig. 1).

Analysis shows that dental gels are quite popular dosage form for treatment of periodontal disease (about a half of presented drugs). This is due to the fact that this dosage form has a high bioavailability, lower toxicity and the maximum effect for treatment of inflammatory diseases of the oral cavity. Analysis of dosage forms of the drugs showed that unoccupied niche in this segment is a group of drugs based on herbal raw materials. This opens up opportunities for Kazakh manufacturers, especially due to the fact, that the country has a strong resource base. In this regard, development of drugs based on the use of domestic raw materials is an important task.

At the next step the analysis of the drugs presented in Kazakhstan market according to manufacturing countries (Fig. 2) was carried out. Results indicate that the market for dental products for topical application depends on import - only 3 out of 15 drugs are manufactured in the Republic of Kazakhstan.

Markets are saturated enough, however, for Kazakh producers there are sufficiently broad niche as domestic manufacturers occupy only $13 \%$ of the market. Particularly interesting are the opening 
$\frac{0}{0}$

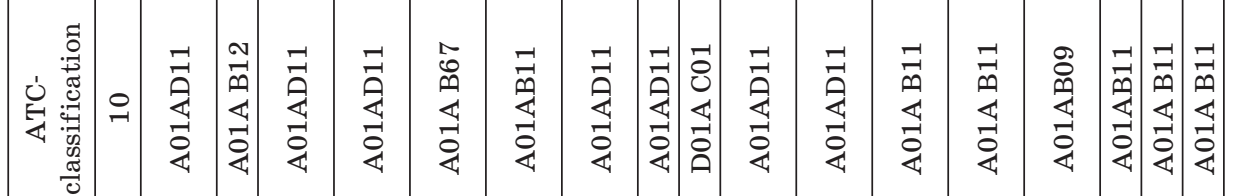

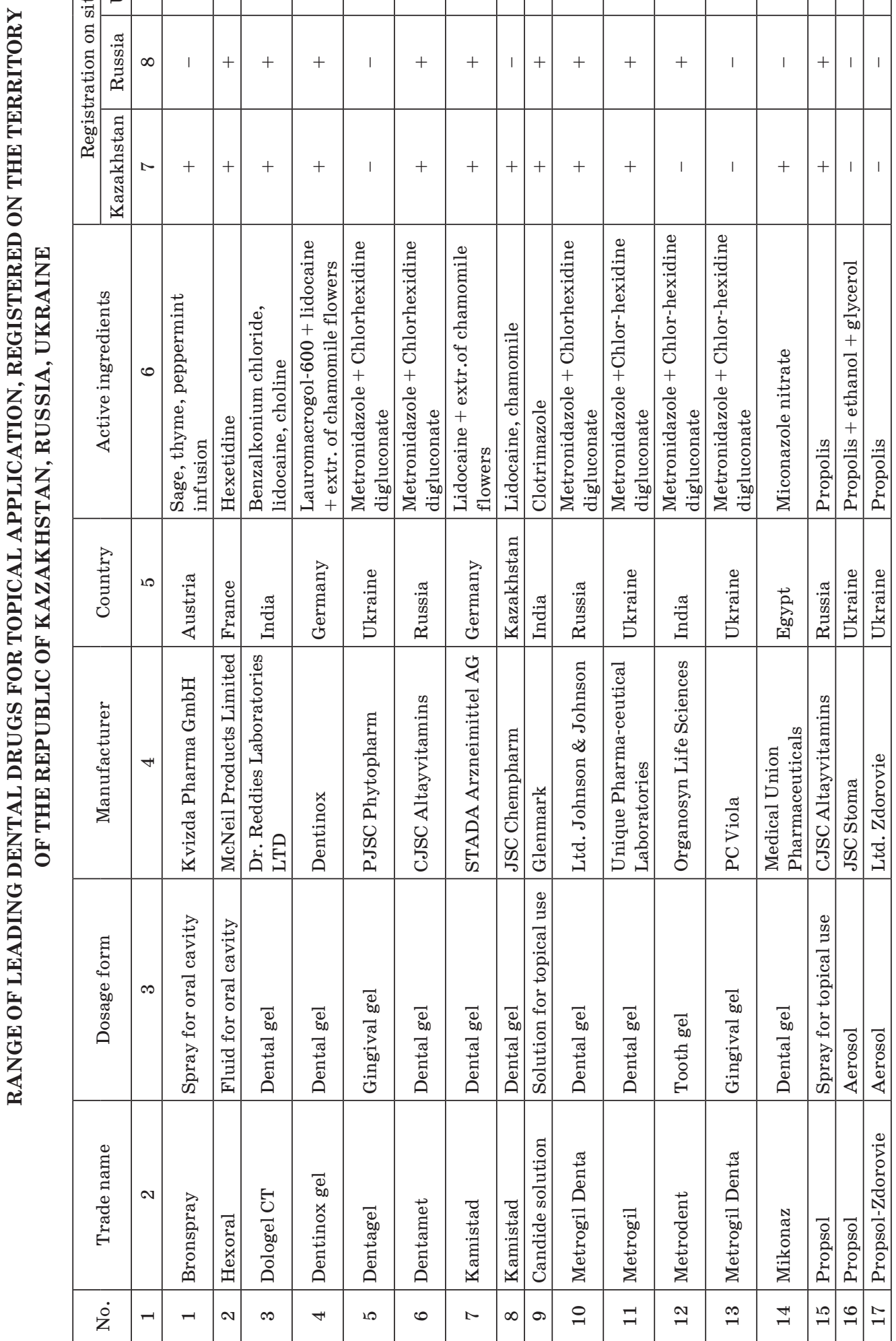


0
0
0
0
0
0
0
0
0
0
0
0
0
0
0
0
0
0
0

\begin{tabular}{|c|c|c|c|c|c|c|c|c|c|c|c|c|}
\hline 윽 & 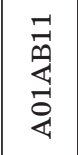 & 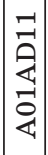 & 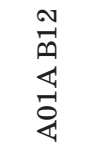 & 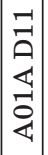 & 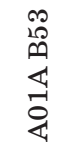 & 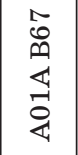 & 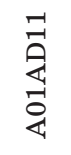 & 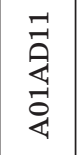 & $\begin{array}{l}\overrightarrow{7} \\
\vec{\ominus} \\
\stackrel{4}{0}\end{array}$ & 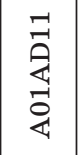 & $\begin{array}{l}0 \\
10 \\
0 \\
4 \\
\vdots \\
0 \\
4\end{array}$ & 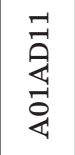 \\
\hline 0 & + & 1 & + & + & + & + & 1 & 1 & 1 & + & + & + \\
\hline$\infty$ & + & 1 & + & + & 1 & 1 & 1 & 1 & + & 1 & + & + \\
\hline$\sim$ & + & + & + & + & + & 1 & + & + & + & 1 & + & + \\
\hline 0 & 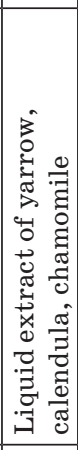 & 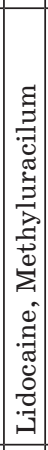 & 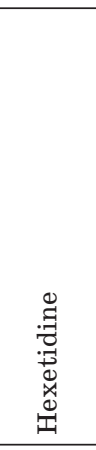 & 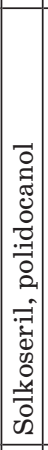 & 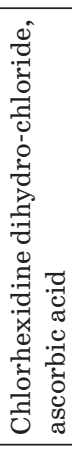 & 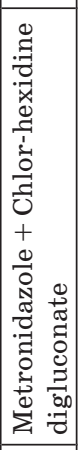 & $\begin{array}{l}: \\
: 7 \\
0 \\
0 \\
0 \\
\stackrel{0}{0}\end{array}$ & 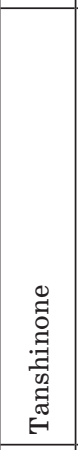 & 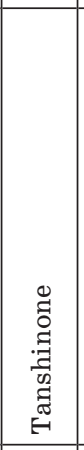 & 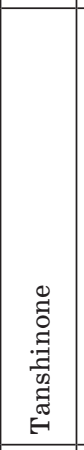 & 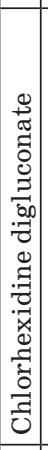 & 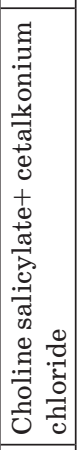 \\
\hline 10 & 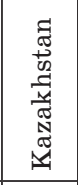 & 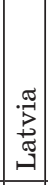 & 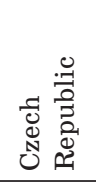 & 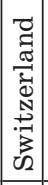 & 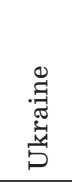 & 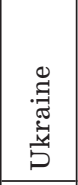 & 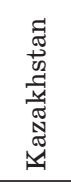 & 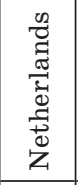 & 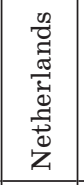 & 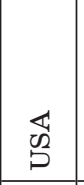 & 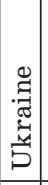 & 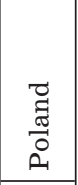 \\
\hline+ & 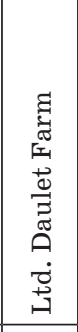 & 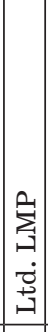 & 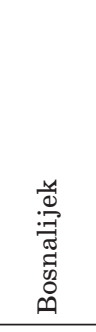 & 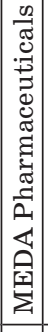 & 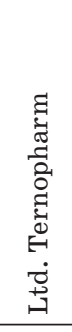 & 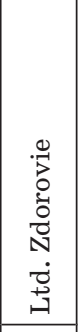 & 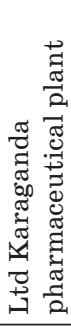 & 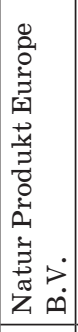 & 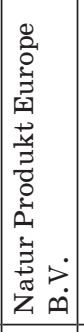 & 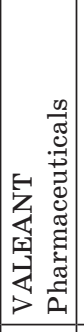 & 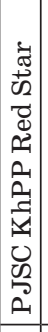 & 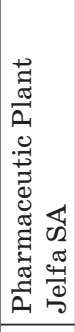 \\
\hline$\infty$ & 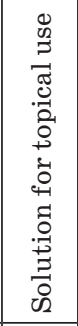 & 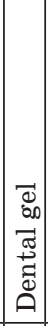 & 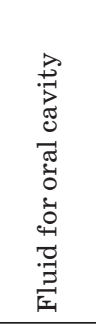 & 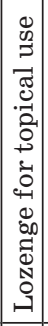 & 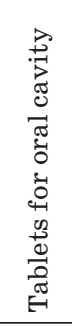 & 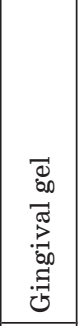 & 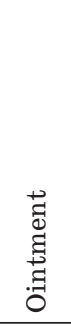 & 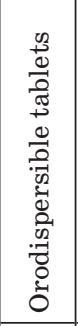 & 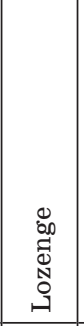 & 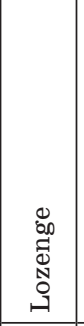 & 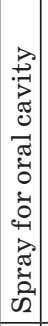 & 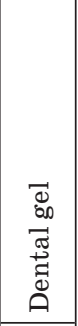 \\
\hline N & 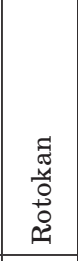 & 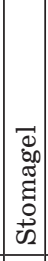 & 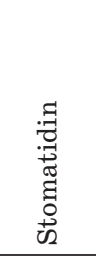 & 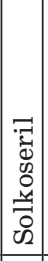 & 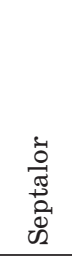 & 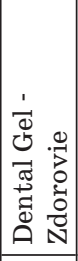 & 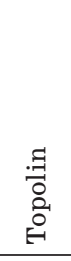 & $\begin{array}{l} \\
\infty \\
\approx \\
\tilde{2} \\
2\end{array}$ & 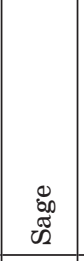 & $\begin{array}{l} \\
\text { on } \\
\text { జू } \\
\tilde{n}\end{array}$ & 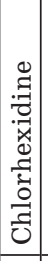 & 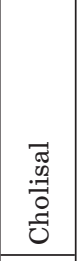 \\
\hline-1 & $\stackrel{\infty}{\sim}$ & $\stackrel{\oplus}{\rightarrow}$ & คิ & $\overrightarrow{\mathrm{N}}$ & ลิ & ๗ & $\stackrel{\vec{N}}{ }$ & ล2 & $\stackrel{\leftrightarrow}{\mathrm{N}}$ & ลั & $\stackrel{\infty}{\sim}$ & จิ \\
\hline
\end{tabular}




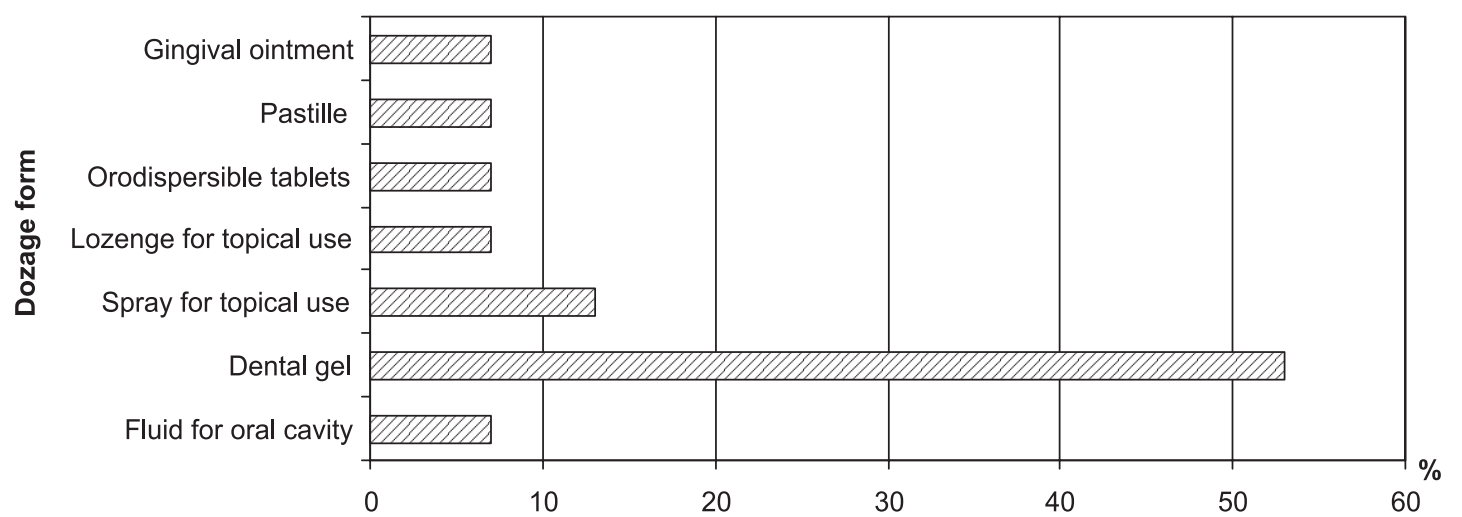

Fig. 1. Structure of dental drugs presented at the market of Kazakhstan, according to the dosage forms
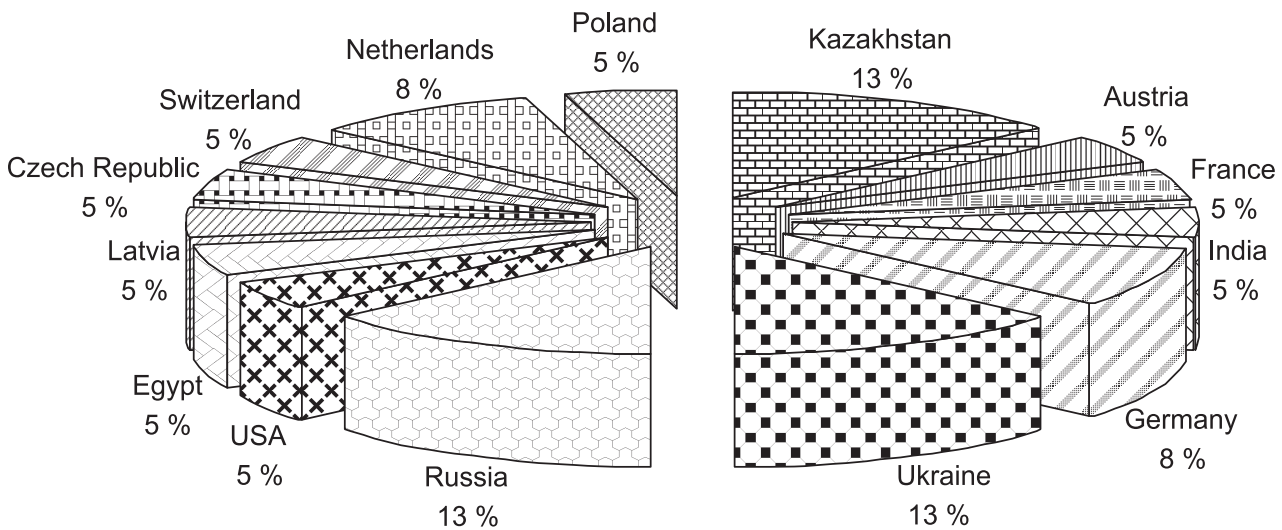

Fig. 2. Analysis of the drugs presented in Kazakhstan market according to manufacturing countries

opportunities at this stage of development of the pharmaceutical market of Kazakhstan. In a crisis, consumers are switching to cheaper drugs. This suggests that domestic companies having obtained additional resources by redistributing consumption towards low price segment can actively build up its product portfolio at the expense of dental drugs for topical use.

Thus, the carried out studies have shown the possibilities and directions of development of the Kazakhstan pharmaceutical industry in the group of the above mentioned drugs. Next stage of the research can be definition of consumer's preferences in this category of drugs, development of offers for the production of certain forms and composition of the drugs, as well as forecasting of possible future sales volumes in the country and neighboring countries.

\section{CONCLUSIONS AND PROSPECTS FOR FURTHER RESEARCH}

Studied pharmaceutical market of Kazakhstan, Russia, Ukraine, studied range of drugs for topical application used in parodontopathy. Analyzed structure of the market, in accordance with the groups of drugs (ATC-classification), dosage form, composition of active ingredients, manufacturing countries.

It was determined that the range of dental products in the market of Kazakhstan and neighboring countries is quite wide. However, Kazakhstan is characterized by low presence of domestic manufacturers in this group of drugs $(13 \%)$ at the market. Were selected the most popular formulations (gels) and widely used formulations of drugs, on the basis of what is possible the development of further offers for Kazakh manufacturers to form product portfolio in the group dental drugs.

In view of these results, development of dental drugs for topical application on the basis of domestic raw materials is an urgent task.

\section{REFERENCES}

1. Глухов А. В. Остеопороз и хроническое обструктивное заболевание легких / А. В. Глухов // Мед. журн. «Новости медицины и фармации». - 2010. - № 318. - С. 28-32.

2. Государственный реестр лекарственных средств, изделий медицинского назначения 
и медицинской техники МЗ РК - [Электронный ресурс]. - Режим доступа: http://www. dari.kz/category/gos_reestr_excel

3. Гуменюк Н. И. Патологические процессы пародонта у больных хроническим обструктивным заболеванием легких / [Н. И. Гуменюк, И. П. Мазур, В. И. Игнатьева и др.] // Астма та алергія. - 2013. - № 3. - С. 28-34.

4. Делендик А. И. Изучение потребности населения в различных видах стоматологической помощи по данным анкетирования // Стоматология. - 2000. - Т. 79, № 6. - С. 58-60.

5. Досжанова Б. А. Стоматологические гели для проведения лечение заболевания полости рта / Б. А. Досжанова, К. К. Кожанова, С. ЖЖ. Абдикаримов // Стоматология Казахстана. - 2013. - № 1 (1). - С. 77-79.

6. Отт Р. В. Клиническая и практическая стоматология / Р. В. Отт. - М.: МЕДпресс-информ, 2010. -640 c.

7. Русанов В. П. Эффективность стоматологического геля с антибиотиком при лечении больных альвеолитом / [В. П. Русанов, Г. С. Стабаева, К. К. Талимов и др.] // Стоматология Казахстана. - 2016. - № 1 (11). - С. 10-16.

8. Справочник лекарственных средств Украины. Компендиум. - [Электронный ресурс].
- Режим доступа: http://compendium.com. ua/medical_product

9. Терещук С. А. Фармакодинамика лекарственных препаратов, используемых в лечении заболеваний СОПР у детей. - [Электронный ресурс]. - Режим доступа: http://sergeytereshchuk.io.ua /s28345/quotfarmakodinamika_lekarstvennyh_ preparatov_ispolzuemyh_v_lechenii_zabolevaniy_ sopr_u_deteyquo

10. Царахов О.А. Маркетинговые исследования локального рынка лекарственных средств, применяемых для профилактики и лечения полости рта / О. А. Царахов, Л. Н. Царахова // Фармация и фармакология. - 2012. - № 5 (12). - С. 69-74.

11. Энциклопедия лекарств и товаров аптечного ассортимента. РЛС-справочник. - [Электронный ресурс]. - Режим доступа: http:// www.rlsnet.ru

12. Яшина Л. О. Особливості етіології та патогенезу остеопорозу у хворих на хронічне обструктивне захворювання легень / Л. О. Яшина // Астма та алергія. - 2013. № 2. - C. 35-41.

13. Lehouck A. COPD, bone metabolism and osteoporosis [Text] / A. Lehouck // Chest. - 2011. - Vol. 139. - P. 648-657. 
УДК 615.322:615.07:616.31-002-08

А. С. Маматова, 3. Б. Сакипова, Р. Б. Аюпова, Г. С. Серикова

АНАЛИЗ КАЗАХСТАНСКОГО ФАРМАЦЕВТИЧЕСКОГО РЫНКА ЛЕКАРСТВЕННЫХ СРЕДСТВ, ПРИМЕНЯЕМЫХ ПРИ ПАРОДОНТОПАТИЯХ

Приведены результаты исследования фармацевтического рынка Казахстана, России, Украины, исследован ассортимент лекарственных средств, применяемых при пародонтопатиях. Проанализирована структура рынка в соответствии с группами применяемых препаратов (АТХ-классификация), лекарственной формой, составом активных ингредиентов. Особое внимание в данном сегменте препаратов уделено казахстанскому фармацевтическому рынку. Изучена структура стран-производителей (казахские производители занимают всего 13 \% рынка), выделены возможности и направления развития для отечественной фармацевтической промышленности в данном сегменте.

Ключевые слова: фармацевтический рынок; стоматологические препараты; парадонтопатии; Республика Казахстан; маркетинговый анализ

УДК 615.322:615.07:616.31-002-08

А. С. Маматова, 3. Б. Сакіпова, Р. Б. Аюпова, Г. С. Серикова АНАЛІЗ КАЗАХСТАНСЬКОГО ФАРМАЦЕВТИЧНОГО РИНКУ ЛІКАРСЬКИХ ЗАСОБІВ, ЩО ВИКОРИСТОВУЮТЬСЯ ПРИ ПАРОДОНТОПАТІЯХ

Наведені результати дослідження фармацевтичного ринку Казахстану, Росії, України, досліджений асортимент лікарських засобів, що застосовуються при пародонтопатії. Проаналізовано структуру ринку відповідно до груп застосовуваних препаратів (АТСкласифікація) за лікарською формою, складом активних інгредієнтів. Особливу увагу в даному сегменті препаратів приділено казахстанському фармацевтичному ринку. Вивчено структуру країн-виробників (казахські виробники займають всього 13 \% ринку), виділені можливості і напрямки для розвитку вітчизняної фармацевтичної промисловості в даному сегменті.

Ключові слова: фармацевтичний ринок; стоматологічні препарати; парадонтопатії; Республіка Казахстан; маркетинговий аналіз

Адреса для листування:

050000, Казахстан, Алматы, Толе-би, 94.

Тел. +7(727)338-70-90, +7(727)292-43-00.

E-mail:info@kaznmu.kz.

Казахский Национальный медицинский университет имени С. Д. Асфендиярова
Надійшла до редакції 27.05.2016 р. 